\title{
RESENHA
}

\section{SUNSTEIN, CASS; HOLMES, STEPHEN. THE COST OF RIGHTS: WHY LIBERTY DEPENDS ON TAXES. NOVA IORQUE: W.W. NORTON \& COMPANY, 1999.}

O livro The Cost of Rights: Why Liberty Depends on Taxes, dos professores Cass Sunstein (Harvard Law School) e Stephen Holmes (New York University School of Law) já é um clássico da literatura jurídica norte-americana. Fundamentada em um argumento aparentemente simples, a obra questiona pilares anteriormente tidos como intocáveis pela teoria constitucional; em especial, problematiza a distinção entre direitos positivos e negativos, tradicional no constitucionalismo liberal, além de discutir os fundamentos econômicos dos direitos fundamentais.

Na presente resenha parte-se da premissa de que The Cost of Rights é uma obra relevante, que merece ser discutida pela academia nacional, e, por isso, pretende-se expor os principais argumentos do livro, bem como denotar aspectos que merecem a devida ponderação.

Inicialmente, é preciso destacar a reputação internacional dos autores da obra, Cass Sunstein e Stephen Holmes.

Cass Sunstein é professor da renomada Harvard Law School, onde ensina disciplinas de Direito Constitucional, Direito Administrativo, Direito Ambiental e Direito e Economia Comportamental (Law and Behavioral Economics). Lecionou por 27 anos na também renomada University of Chicago Law School. Em 2007, recebeu o prêmio Henry M. Phillips da American Philosophical Society, pelo "reconhecimento de sua liderança intelectual em direito constitucional e ciência política" (tradução nossa). Sunstein também foi Secretário do White House Office of Information and Regulatory Affairs na primeira administração de Barack Obama.

Foi, ainda, agraciado com o título de Harvard University Professor, criado em 1935 em honra aos indivíduos cujo trabalho inovador ultrapassa as fronteiras de múltiplas disciplinas. ${ }^{1}$ Ao conceder a distinção, Drew Faust, Presidente da Universidade Harvard, disse o seguinte:

[...] o trabalho acadêmico de Cass Sunstein lançou novas luzes sobre questões tradicionais e abriu novos caminhos para juristas, baseando-se criativamente em campos estranhos ao direito para oferecer insights que enriquecem consistentemente não apenas o discurso jurídico, mas também o mundo mais amplo das ideias. (SUSTEIN..., 2013).

Destaque-se que algumas de suas obras já foram traduzidas para o português, como Nudge: o empurrão para a escolha certa (ELSEVIER, 2009) e A Constituição Parcial (DEL REY, 2008).

Stephen Holmes, por sua vez, desde 2000 é professor da também renomada New York University School of Law, onde também lecionou Ronald Dworkin. Antes, foi professor de Política

\footnotetext{
1 Lista de laureados disponível em: <http://www.harvard.edu/university-professorships>.
} 
da Princeton University (1997-2000), de Ciência Política e Direito na University of Chicago (19851997) e de Administração Pública em Harvard (1979-1985). Publicou diversos livros e artigos sobre liberalismo, constitucionalismo e limites constitucionais da repressão ao terrorismo. Foi, ainda, editor-chefe da importante revista acadêmica East European Constitutional Review, entre 1993 e 2003.

Entre seus livros, destacam-se Passions and Constraint: On the Theory of Liberal Democracy, publicado em 1995 pela University of Chicago Press, The Anatomy of Antiliberalism (Harvard University Press, 1993) e Benjamin Constant and the Making of Modern Liberalism (Yale University Press, 1984).

O argumento central do livro The Cost of Rights é o de que sempre há custos inerentes ao exercício de direitos. Esses custos não têm apenas natureza financeira, mas também decorrem de custos de oportunidade derivados da proteção de pretensões jurídicas que excluem outras. Quando o direito à propriedade de um latifúndio improdutivo é protegido, o acesso àquela terra é negado a invasores que pretendiam cultivá-la. Para proteger esse direito, por exemplo, é necessário custear a atividade policial para impedir a invasão da propriedade, além da manutenção das instituições judiciárias, necessárias para que um juiz determine a restituição da posse. Mas, para além do valor monetário necessário à manutenção dessas instituições, há também custos de oportunidade: os policiais poderiam estar, naquele momento, atuando em outra ocorrência. $O$ juiz poderia estar trabalhando em outro caso. A propriedade da terra poderia ser mais produtiva caso fosse explorada pelos invasores, não pelo proprietário atual.

Esse raciocínio é aplicável a toda a miríade de direitos protegidos pelo ordenamento jurídico. A proteção da propriedade privada depende da existência não apenas de tribunais e policiais, mas também de bombeiros e prisões para punir os violadores desse direito. $\mathrm{O}$ direito à liberdade de expressão depende não apenas da proteção policial para impedir os que procurem criar obstáculos a seu exercício, mas também da manutenção de uma estrutura institucional que garanta de fato o exercício desse direito, possibilitando a criação e a livre atuação de editoras, jornais, revistas, canais de televisão, blogs, entre outros canais da livre expressão. $\bigcirc$ direito à educação depende da existência, de fato e em boa qualidade, de escolas e professores. O exercício do direito ao sufrágio depende da manutenção de tribunais eleitorais, bem como da aquisição de computadores para registro dos eleitores e candidatos. A singela, mas poderosa, mensagem do livro é essa: o exercício de direitos traz custos.

O que parece óbvio não é tão evidente assim na teoria jurídica, que desde o século XIX tem aceito de forma relativamente acrítica a distinção entre direitos positivos e direitos negativos. Direitos negativos seriam assegurados, na acepção clássica, desde que o Estado não interferisse em sua fruição. Como exemplo, estão o direito à vida (o direito de o Estado não retirar a vida de nenhum cidadão) ou o direito à liberdade religiosa (o direito de o Estado não interferir na escolha religiosa). Direitos positivos, por outro lado, dependeriam da intervenção direta do Estado para assegurar as condições de seu exercício. ${ }^{2}$ É o caso, por exemplo, do mencionado direito à educação, que depende

2 Entre os exemplos de direitos negativos usualmente citados estão os de propriedade, liberdade de expressão, liberdade religiosa, liberdade de associação - direitos também consagrados como de primeira geração ou DE primeira dimensão. Entre 
da construção de escolas e da contratação de professores, ou do direito à saúde, que depende de uma estrutura institucional pública que preste por si só ou forneça incentivos para que particulares construam hospitais e prestem serviços no setor (ou, como no Brasil, utilize um modelo misto).

Cass Sunstein e Stephen Holmes não aceitam a distinção entre direitos positivos e direitos negativos tão facilmente. O principal objetivo de The Cost of Rights é eliminar essa distinção conceitual - ou reconstruí-la - de modo a demonstrar que todos os direitos dependem do dispêndio de recursos orçamentários. Nas palavras dos próprios autores:

Where there is a right, there is a remedy" is a classical legal maxim. Individuals enjoy rights, in a legal as opposed to a moral sense, only if the wrongs they suffer are fairly and predictably redressed by their government. This simple point goes a long way toward disclosing the inadequacy of the negative rights/positive rights distinction. What it shows is that all legal -ly enforced rights are necessarily positive rights. (SUSTEIN; HOLMES, 1999, p. 43).

Esse tema permeia toda a obra, ilustrando uma temática subjacente ainda mais profunda e que diz respeito a toda a estrutura do direito moderno. Afinal, o que são direitos? $\mathrm{Na}$ abordagem proposta, considerações de cunho orçamentário estão na raiz de qualquer discussão sobre o próprio conceito de direito subjetivo: "As a general rule, unfortunate individuals who do not live under a government capable of taxing and delivering an effective remeda have no legal rights. Statelesness spells rightslessness. A legal right exists, in reality, only when and if it has budgetary costs." (SUSTEIN; HOLMES, 1999, p. 19).

Isso porque a existência concreta de um direito somente pode ser afirmada se existem remédios jurídicos capazes de assegurá-lo efetivamente - o que exige o custeio de instituições operacionalmente eficientes, com quadro de funcionários e recursos físicos, logísticos, financeiros e técnicos suficientes para o bom exercício de sua função. Por essa razão, Sunstein e Holmes (1999, p. 43-44) afirmam que:

$[R]$ ights are costly because remedies are costly. Enforcement is expensive, especially uniform and fair enforcement; and legal rights are hollow to the extent that they remain unenforced. For-mulated differently, almost every right implies a correlative duty, and duties are taken seriously only when dereliction is punished by the public power drawing on the public purse. There are no legally enforceable rights in the absence of legally enforceable duties, which is why law can be permissive only by being simultaneously obligatory. That is to say, personal liberty cannot be secured merely by limiting government interference with freedom of action and association. No right is simply a right to be left alone by public officials. All rights are claims to an affirmative governmental response.

Direitos, na concepção de Sunstein e Holmes, portanto, são reivindicações por uma resposta governamental afirmativa. Um indivíduo somente tem um direito se o Estado puder intervir para assegurá-lo. Direitos não são nem fruto de um discurso lastreado na filosofia moral nem, tampouco, características da natureza humana.

Essa definição de direito também é inovadora na tradição jurídica, já que coloca a efetividade no centro das discussões jurídicas. Ao contrário do formalismo kelseniano ou da ênfase 
interpretativa de Ronald Dworkin, que tanta influência tiveram no direito brasileiro, mas que se concentram na lógica operacional interna das instituições jurídicas, Sunstein e Holmes propõem uma análise interdisciplinar. Não é possível, segundo a proposta dos autores, discutir o direito sem discutir política, porque a finalidade das instituições jurídicas somente pode ser cumprida mediante a atribuição dos recursos necessários a esse fim pelas instituições políticas. Em outras palavras, não há direito sem governo.

Outro ponto de destaque da obra diz respeito ao modo como ela supera a dicotomia que opõe, no cenário norte-americano, liberais e comunitaristas. Segundo a abordagem liberal clássica, a sociedade civil é organizada mediante a associação de indivíduos livres e iguais que, por um ato de vontade, decidem firmar um contrato social pelo qual se estabelecem os limites a serem observados pelo governo comum, a fim de proteger os direitos individuais. Essa abordagem, que une a filosofia liberal de Hobbes a Rawls, foi duramente atacada, a partir da década de 1970, por pensadores conhecidos como "comunitaristas", e que incluem teóricos como Alasdair MacIntyre, Michael Sandel, Charles Taylor e Michael Walzer. As críticas delineadas por esses autores dirigiram-se à forma com que os liberais concebem a organização social, a partir da união entre indivíduos "atomizados", isolados uns dos outros. Para os comunitaristas, a sociedade é, antes de tudo, uma comunidade, que antecede os indivíduos e determina seu horizonte de possibilidades. A sociedade não é a união de indivíduos isolados, mas um todo holístico superior aos indivíduos que dela fazem parte.

A perspectiva de Sunstein e Holmes, contudo, é intermediária entre ambas as posturas. Sem traçar uma análise filosófica mais densa da polêmica entre liberais e comunitaristas, os autores sustentam que a consciência de que direitos têm custos entrelaça as concepções liberais e comunitaristas. Direitos têm custos, e esses custos são financiados pelos impostos pagos pela sociedade civil. A proteção da liberdade individual, portanto, somente pode ser efetivada pelo estabelecimento de impostos, que nada mais são que uma forma comunitária de cooperação institucionalizada. "Rather than reflecting a blind worship of market outcomes, that is to say, the study of the cost of rights is meant to encourage thoughtful public policy. It is also a kind of communitarian or collectivist theme, though with deep roots in the liberal political tradition." (SUSTEIN; HOLMES, 1999, p. 224).

Além da oposição entre direitos positivos e direitos negativos, The Cost of Rights também questiona outras oposições conceituais que, muitas vezes, são aceitas sem maiores questionamentos: direito público e direito privado, governo e livre mercado, direito civil e direito penal. Todas essas distinções, na obra, são questionadas por trazerem mais confusões do que esclarecimentos. Apenas a título de exemplo, trago as seguintes passagens do texto a respeito da distinção entre direito público e direito privado:

THE IDEA THAT RIGHTS ARE ESSENTIALLY AIMED "against" government, rather than calling on government, is patently wrong when applied to what is sometimes called "private law." Rights in contract law and tort law are not only enforced but also created, interpreted, and revised by public agencies. At both federal and state levels, courts and legislatures are constantly creating and readjusting the legal rules that give meaning to rights, as well as specifying and respecifying the various exceptions to these rules. By adjudication and legislation, public authorities not only enforce contracts but also decide which contracts are enforceable and which are unenforceable, unconscionable, or otherwise 
meaningless pieces of paper. Judges and legislators not only award damages to the victims of negligence but also identify which excuses are legally acceptable for what might otherwise be classified as negligent behavior.

$[\ldots]$

When I sue someone under contract or tort law, I am not trying to get the government "off my back"; I am trying to get it "on my case" In private law, the rightsholder does not need government forbearance; he needs government performance. (SUSTEIN; HOLMES, 1999, p. 50).

Os direitos privados, nesse sentido, dependem de uma estrutura pública para serem usufruídos. Contratos são firmados com base em estrutura jurídica, que somente é considerada válida se atender às prescrições legais, e sua execução demanda a intervenção de autoridades.

Em outra parte do texto, Sunstein e Holmes também desconstroem a oposição entre governo e livre mercado, afirmando que o próprio mercado depende de uma estrutura jurídica institucional que assegure as condições procedimentais necessárias ao seu bom funcionamento:

But if private rights depende essencial on public resources, there can be no fundamental opposition between 'government' and 'free markets' [...] But the first thing a government must do to make a market system work is to overcome the age-old rule of force and threats of force. Free markets do not function properly if profit-seekers uninhibitedly engane in criminal violence. (SUSTEIN; HOLMES, 1999, p. 70-71).

Além disso, as características do sistema jurídico podem promover reflexos funcionais ou disfuncionais no sistema econômico, promovendo a riqueza ou a pobreza - algo que o best-seller Por que as Nações Fracassam, de Daron Acemoglu e James Robinson, também sustenta. A estrutura institucional define oportunidades e resultados dos cidadãos afetados por ela, criando e distribuindo riqueza de maneira igual ou desigual: The public costs of non-welfare rights show, among other things, that 'private wealth,' as we know it, exists only because of governmental institutions. (SUSTEIN; HOLMES, 1999, p. 29).

E em outra passagem:

Inequality of results will always be inescapable so long as rights impose private as well as public costs. Every American citizen has the right to sue the police for civil damages, but only a party with substantial private resources has a fighting chance to do so successfully. Those most likely to suffer police abuse ordinarily have no such resources and hence, in practice, enjoy no such right. (SUSTEIN; HOLMES, 1999, p. 202).

Também a distinção funcional entre direito civil e direito penal é colocada em perspectiva pelos autores. De acordo com Sunstein e Holmes (1999, p. 61), ambos procuram, por instrumentos diferentes, punir violadores de direitos:

Government must obviously help maintain owner control over resources, predictably penalizing force and fraud and other infractions of the rules of the game. Much of the civil law of property and tort is designed to carry out this business. And the criminal justice system channels considerable public resources to the deterrence of crimes against property: larceny, burglary, shoplifting, embezzlement, extortion, the forging of wills, receiving stolen goods, blackmail, arson, and so forth. The criminal law (inflicting punishments) and the civil law (exacting restitution or compensation) conduct a permanent, two-front, and publicly financed war on those who offend against the rights of owners. 
Todos esses aspectos, profundamente discutidos em The Cost of Rights, já asseguram ao livro um lugar de referência na filosofia jurídica internacional.

É importante ressaltar, ainda, que o fato de que os autores tenham escrito o livro com base na experiência jurídica norte-americana (e a invocarem em várias passagens do texto) não o tornam menos interessante como referência também no Brasil. Apesar de ter sido escrito a partir de uma matriz epistemológica de common law, diversa da tradição jurídica brasileira (sistema de civil law), a tese defendida também se aplica a outros países - e, evidentemente, também ao Brasil. ${ }^{3}$

Os debates travados na obra também são de muita relevância para o contexto nacional, que traz incorporadas à filosofia jurídica dominante várias das distinções questionadas na obra, em especial, a relação entre direito civil e penal, bem como a oposição entre direitos positivos e negativos e entre direito público e privado. Ainda são raras as obras nacionais (ou traduzidas para o português brasileiro) que abordam essas questões de natureza crítica, razão pela qual acredito que a tradução do texto seria extremamente recomendável.

The Cost of Rights é organizado em quatro partes, sendo as duas primeiras dedicadas à tese central do livro de que direitos têm custos e à análise orçamentária dos direitos. Nesses capítulos, os autores conceituam direitos como interesses que podem ser protegidos por meio do uso de instrumentos institucionais (SUSTEIN; HOLMES, 1999, p. 16). Direitos somente existem legalmente a partir do reconhecimento estatal e da estipulação de orçamento financeiro para custear a sua proteção. A mera asserção de um direito é inútil, ineficaz para de fato implementá-lo. Apenas com a alocação de recursos públicos para a proteção de determinado direito é possível dizer que ele foi, de fato, reconhecido institucionalmente como tal.

Na primeira parte da obra, apresenta-se a tese de que a garantia de direitos pressupõe a existência de um aparato institucional destinado a protegê-los, que necessita de recursos para ser mantido. É aqui que Sunstein e Holmes exploram a tese de que a distinção entre direitos negativos e positivos precisa ser repensada, considerando que todos os direitos demandam recursos estatais - e, portanto, todos os direitos são, em última instância, positivos. Além disso, critica-se a ideia de que os direitos de primeira dimensão seriam "direitos contra o governo", porque a sua proteção depende, na verdade, de instituições atuantes e em bom funcionamento.

No terceiro capítulo, os autores dedicam-se a examinar a relevância do pagamento de impostos para a manutenção de direitos - em especial, o direito de propriedade. Impostos, nessa visão têm por finalidade custear as instituições que protegem direitos:

What needs to be added to these observations is the correlative proposition that property rights depend on a state that is willing to tax and spend. Property rights are costly to enforce. To identify the precise monetary sum devoted to the protection of property rights, of course,

\footnotetext{
3 Como disse Palmer (1999, p. 332) em resenha da obra: "Setting aside the claim that this is a matter of 'American law', let's examine the case they advance for positivism, i.e., for the thesis that law and rights are posited or laid down rather than discovered or recognized. First, they claim that focusing only on legal rights, i.e., those rights that are actually enforced by a political authority with the power to secure compliance, 'can be justified by an enhanced clarity of focus' (p. 21). That is the promise, but nowhere do they fulfill it. Instead, they produce an account of rights that is both incoherent and self-contradictory."
} 
raises difficult issues of accounting. But this much is clear: a state that could not, under specified conditions, "take" private assets could not protect them effectively, either. The security of acquisitions and transactions depend, in a rudimentary sense, on the government's ability to extract resources from private citizens and apply them to public purposes. On balance, property rights may even place a charge upon the public treasury that vies with the burden of our massive entitlement programs. (SUSTEIN; HOLMES, 1999, p. 61).

Na segunda parte do livro, Sunstein e Holmes discutem a tese de que direitos não podem ser absolutos. E o primeiro capítulo dessa parte (capítulo cinco) mostra o porquê: a escassez de recursos afeta a liberdade. A tese é simples e direta: quando consideramos que a proteção de direitos tem custos e que os recursos destinados ao custeio da estrutura institucional destinada a esse fim são limitados, reconhece-se a necessidade de uma decisão política a respeito de como esses recursos serão alocados (tema do capítulo 7), considerando-se que os trade-offs entre direitos são inescapáveis (discussão do capítulo 8).

E essa decisão, por sua vez, tem como consequência que algumas pessoas terão seus direitos protegidos e outras não.

Direitos são usualmente descritos como invioláveis, peremptórios e conclusivos. Mas isso é mero floreio retórico. Nada que custa dinheiro pode ser absoluto. Nenhum direito cuja aplicação pressupõe um gasto seletivo de dinheiro dos contribuintes pode, no fim das contas, ser protegido pelo Judiciário sem considerar as consequências orçamentárias sobre as quais os outros poderes têm responsabilidade (SUSTEIN; HOLMES, 1999, p. 97, tradução nossa).

Assim, a aplicação de direitos é concebida como uma discussão a respeito de como os recursos deveriam ser distribuídos.

A terceira e a quarta parte do livro dedicam-se a discutir a importância do discurso público baseado em direitos. A liberdade, na perspectiva da obra, deriva da dependência de um determinado conjunto de instituições liberais, não da ausência de intervenção estatal na esfera de liberdade dos indivíduos. $O$ potencial de crítica derivado desse ponto de vista é profundo: não apenas os pobres dependem do governo e do direito para proteger direitos à redistribuição de renda, mas também os ricos, pois seu direito de propriedade também depende da existência de instituições capazes de protegê-lo. E essa estrutura institucional é responsável em grande medida pelo sucesso ou fracasso dos indivíduos.

A passagem a seguir é bem ilustrativa da perspectiva dos autores:

Unless society is organized as a cooperative venture, private property as we know it cannot be created and maintained. Large American corporations could never have developed their current wealth and power without many kinds of government support. Similarly, wealthy and successful individuals owe their riches and success to social institutions that, while demanding cooperation from all, distribute rewards selectively and unequally. A capitalist economy provides the legal preconditions for the unequal accumulation of wealth. Such unequal accumulations do not fall from the sky. However hard people work, it is always an oversimplification to attribute differences of acquired wealth solely to the wealthy's "own efforts". (SUSTEIN; HOLMES, 1999, p. 192-193).

$\mathrm{E}$, se as desigualdades podem ter como origem instituições que estruturam o modelo de cooperação de uma dada sociedade, é possível corrigi-las mediante o uso dos direitos como estraté- 
gias de inclusão. Os direitos são a maneira pela qual as instituições integram cidadãos de sociedades complexas em uma vida social comum. Impostos custeiam direitos, que tornam possível estruturar a cooperação na relação entre cidadãos que, fora a vida em comum sob a égide do mesmo direito, têm pouco em comum. Essa é a grande mensagem do livro: direitos têm custos, mas vale a pena pagá-los.

É preciso destacar, ainda, que o livro The Cost of Rights já foi mencionado em alguns acórdãos do Supremo Tribunal Federal. $O$ último desses casos foi julgado em 04 de novembro de 2014 (ARE n. 727864), tendo como Relator o Ministro Celso de Mello. No caso, o livro foi mencionado como referência importante na discussão a respeito do princípio da reserva do possível.

Em 23 de outubro de 2014, o Ministro Gilmar Ferreira Mendes citou textualmente a obra no ARE n. 704520/SP, julgado pelo Tribunal Pleno do STF. Transcrevo o trecho da decisão que mencionou o livro:

Essa postulação de que se conceda ultratividade à lei revogada, na verdade, vai de encontro à própria realidade dos fatos, na medida em que os direitos sociais - como, de resto, qualquer dos direitos fundamentais - demandam ações positivas e têm custos que não podem ser ignorados pelo poder público, tampouco pelos tribunais. Lembro, de passagem, a ilustrativa doutrina de Sustein e Holmes (1999, p. 97) quando afirma: "Rights are familiarly described as inviolable, preemptory, and conclusive. But these are plainly rhetorical flourishes. Nothing that costs money can be an absolute."

Vale dizer: levar os direitos a sério requer que se considerem também os custos de sua efetivação, que, aliás, serão tanto mais relevantes quanto mais dispendiosa seja a concretização do direito ou da política pública em questão.

Em outro julgado (Ag. Reg. na Suspensão de Liminar n. 47/PE, julgado pelo Tribunal Pleno do STF em 17 de março de 2010), o Relator, Ministro Gilmar Mendes também invocou a obra, nos seguintes termos:

Ressalto, nessa perspectiva, as contribuições de Stephen Holmes e Cass Sunstein para o reconhecimento de que todas as dimensões dos direitos fundamentais têm custos públicos, dando significativo relevo ao tema da "reserva do possível", especialmente ao evidenciar a "escassez dos recursos" e a necessidade de se fazerem escolhas alcovitas, concluindo, a partir da perspectiva das finanças públicas, que "levar a sério os direitos significa levar a sério a escassez." (HOLMES; SUNSTEIN, 1999).

Menções ao livro na Suprema Corte brasileira já vêm desde pelo menos 2005 (RE n. 410715/ SP, Relator Ministro Celso de Mello, julgado em 22 de novembro de 2005 pela Segunda Turma), apenas seis anos após a sua publicação. Isso demonstra a relevância do texto no contexto nacional, considerando a sua incorporação, ainda que superficial, como doutrina na mais alta Corte do País.

\section{Referências}

SUSTEIN a University Professor. Harvard Gazette, Feb. 19 2013. Disponível em: < http://news. harvard.edu/gazette/story/2013/02/sunstein-a-university-professor/>. Acesso em: 12 jan. 2015. 